\title{
Exploring Elementary Thai Teachers' Use of Mathematics Textbook
}

\author{
Suwarnnee Plianram ${ }^{1}$, Maitree Inprasitha ${ }^{2}$ \\ ${ }^{1}$ Department Doctoral Program in Mathematics Education, Faculty of Education, Khon Kaen University, \\ Khon Kaen, Thailand \\ ${ }^{2}$ Center for Research in Mathematics Education, Faculty of Education, Khon Kaen University, \\ Khon Kaen, Thailand \\ Email: plianram_crme@kku.ac.th
}

Received August 23 $3^{\text {rd }}$, 2012; revised September 25 ${ }^{\text {th }}$, 2012; accepted October $16^{\text {th }}, 2012$

\begin{abstract}
The aim of this study was to compare the approaches to use mathematics textbooks on primary school in-service teachers in the "Project for Professional Development of Mathematics' teacher through Lesson Study and Open Approach". The methodology is questionnaires-check lists, interviews and open ended questionnaires. The results on the approaches on teachers' use of mathematics textbook found that the percentage of adherence and elaboration decrease and the percentage of creation increase after teachers attend the project.
\end{abstract}

Keywords: Teachers’ Use of Mathematics Textbook; Mathematics Textbook

\section{Introduction}

Fan \& Zhuo (2007) stated that textbooks are a key component of the intended curriculum and various researches have revealed that the teaching approaches adopted by classroom teachers and those embodied in the textbooks used in their classroom were often highly alike. That shows influence of textbooks to teacher for teaching in classroom. The TIMSS survey also found that the majority of mathematics teacher used textbook as the main written source when they selected teaching approaches. In general the textbooks were recognized as major information regarding to material content and pedagogical styles in classroom (Haggarty \& Pepin, 2001). The textbooks very much affect the teachers' teaching they use it for selecting the topics to be taught, planning for teaching and sequence of teaching as well as teaching techniques (Fan \& Zhuo, 2002).

Moulton (1997) suggested that it is difficult to find out how teachers use textbooks without actually observing them and to find out what they think about their use without actually asking them. Because the availability of textbooks does not assure their use, and because their use varies considerably from teacher to teacher, observing how teachers use textbooks and asking them why they use them as they do will reveal significant information about the teaching-learning process and how it can be improved.

\section{Characteristics of Mathematics Textbooks}

\section{Characteristics of Thai Mathematics Textbooks}

Inprasitha (1997) analyzed first grade to ninth grade Thai mathematics textbooks; It was found that Thai mathematics textbooks from first grade to ninth grade contain mostly routine exercises aiming at drilling computation skills or revising some rules or principles which have been learnt in the class. There was a general structure and a basic pedagogical and epistemological assumption underlying Thai mathematics textbooks. For the structure, it contains examples that were used to introduce techniques, rules or principles including a conclusion about those techniques, rules or principles. There are a lot of exercises provided for students to practice those techniques, rules or principles. The pedagogical assumption was that students are expected to master the techniques, rules or principles as required in the curriculum. In this sense, the epistemological assumption (i.e. how students come to know mathematics) was that the students have mastered the set of such techniques, rules or principles which comprise their mathematical knowledge and understanding. Characteristics of textbooks for elementary school: The first part of each unit contains routine exercises for drilling computational skill, word problems appeared at the end of each unit, and these word problems are routine exercises, and most of the word problems in the first and second grades require the students to write symbolic sentence before solving the problem.

Inprasitha (2003) suggested that, in Thailand, mathematics teachers used textbooks more than any other sources of information and they were instruction media for teachers, there were up to $90 \%-95 \%$. Teachers used textbook in teaching their mathematics class through lectures follows contents in mathematics textbooks and assigning the students to do exercise in the text with most of them still focusing on calculation in topics as well as short time problem solving for examination preparation. The mathematics teaching in that sense, was analogous to talking mathematics only. The students didn't have an opportunity in learning by themselves. As a result, they lacked of context or situation enhancing mathematical learning process especially the integral mathematics process. It was shown that the textbook was the most important thing affecting the teacher's teaching which also had an impact on the students' mathematical learning process as well.

\section{Characteristics of Japanese Mathematics Textbooks}

According to Murata (2007), Japanese mathematics text- 
books used representations to create space for students to analyze contexts using mathematics. The purpose of the contextual problems was used for mathematical analysis and explorations focus on visual representations for support student learning of mathematics. The Japanese lesson structure is different. A lesson begins with one problem, students take time to represent, explain, solve, and discuss the problem and their approaches to solving the problem. Problems in Japanese textbooks are often "worked out" and relevant representations support the entire problem-solving process. (Mayer, Sims, \& Tajika, 1995 cf.; Murata, 2007). Takahashi (2006) stated that Japanese mathematics lessons, especially for elementary grades, include a significant amount of problem solving. This instructional approach, called structured "problem solving", was designed to create interest in mathematics and stimulate creative mathematical activity in the classroom through students' collaborative work. The lesson usually starts with students working individually to solve a problem using their own mathematical knowledge. After working with problems, students bring various approaches and solutions to classroom discussion. The teacher then leads students in a whole-class discussion in order to compare individual approaches and solutions. This whole-class activity provides students with opportunities to develop their mathematical abilities including conceptual and procedural understanding. When we look closely at Japanese mathematics textbooks, the use of carefully selected problems and activities for improve mathematics' concepts and mathematics' processes of students.

\section{Teachers' Use of Mathematics Textbook}

Lee (2011) suggested that mathematics textbooks as the fundamental resource for lessons, the textbook are always used to identify the educational objectives and regulate the content and boundaries of the learning experiences. Thus, mathematics textbooks plays an important role in teachers' teaching and students' learning processes. Moulton (1997) suggested that when educators conduct research on textbooks, they most often look at the quality of the books-their content and format-and their appropriateness for students in terms of level of vocabulary and ethnic and gender biases. Assuming that textbooks dictate the content of most instruction. Educators, parents, and politicians want to know what the books have to say, what does it matter if what the book say to make students do not learn from them. Educators must know based on evidence about how teachers use textbooks and how their use aids student learning.

Lee (2011) stressed that "making good textbooks does not necessarily lead to effective use in the classroom teaching" because some teachers use lessons directly from the textbook and its organization, others use textbooks as a resource when considering and selecting context and determining the content order through their own reasons and some teachers never use the textbooks for their lessons. Then research exists on how teachers use textbooks, especially in the use of mathematics.

Moulton (1997) suggested that it is difficult to find out how teachers use textbooks without actually observing them and to find out what they think about their use without actually asking them. Because the availability of textbooks does not assure their use, and because their use varies considerably from teacher to teacher, observing how teachers use textbooks and asking them why they use them as they do will reveal significant information about the teaching-learning process and how it can be improved.

\section{Context of This Research}

Inprasitha (2004) stated that after Thailand had an educational reform according to National Educational Act 1999, most of teachers had to develop their own teaching. But, unfortunately, teachers lacked of innovation for developing their own routine works. Most of them still used traditional teaching emphasizing on the contents by overlooking the importance of the students' learning process and attitude toward learning with understanding.

As widely known, Lesson Study is a comprehensive and well-articulated process for examining and supporting practice many Japanese teachers (Fernandez, Cannon, \& Chokshi, 2003 cf.; Inprasitha, 2004). In fact, recently a number of American researchers and educators have suggested that lesson study might be an incredibly beneficial approach to examining practices for US teachers (Lewis, 2002; Fernandez et al., 2003 cf.; Inprasitha, 2004).

Lewis, Perry, \& Hurd (2004) stated that "Lesson study is not just about improving a single lesson. It's about building pathways for ongoing improvement of instruction”.

Watanabe, Takahashi \& Yoshida (2008) stated that Lesson study practitioners need to understand what is involved in the planning of the lesson. When teachers begin their planning, they initially engage in a practice called kyozaikenkyu (Literally study of instructional materials). This practice is a central activity in teachers' everyday practice. It plays a particularly important role in lesson study. However, research indicates that textbooks do play a central role in schooling for teacher. So, studying textbooks is an important part of the literary study of instructional materials.

Inprasitha (2004) stated that Thailand started innovation of lesson study for developing the teachers in Mathematics program. This attempt was expanded to the teaching professional development based on the lesson study as well. For application of lesson study in Thai context, it was developed and modified to be appropriate with Thai schools beginning from collaboratively design research lesson (Plan), collaboratively observing their friend teaching the research lesson (Do), collaboratively doing post-discussion or reflection on teaching practice (See), with following characteristics:

According to Inprasitha (2010), lesson study in Thai context consisted of 3 major phases as:

Phase 1: The phase of collaboratively design research lesson (Plan) among the researcher, co-researchers, and participant teachers. Starting from determination of mathematics activities using in Open-ended problem. Then, the lesson plan was implemented by using the open approach as teaching apporach.

Phase 2: The phase of collaboratively observing their friend teaching the research lesson (Do), in this phase, the lesson plan was used in classroom by teacher. In addition, the teaching in classroom was observed by researcher team, and other teachers. The teaching objective was to observe the students' mathematical ideas, not consider the teacher's teaching competency.

Phase 3: The phase of collaboratively doing post-discussion or reflection on teaching practice (See), regarding to the findings from teaching observation for improving the lesson plan, and using modified lesson plan in class again in the next year.

Inprasitha (2010) state that in Thailand, the schooling of Mathematics in schools on the project of Mathematics Teaching Professional Development by innovation of Lesson Study and Open Approach in 2009 of Center for Research in Mathematics Education, Faculty of Education, Khon Kaen University, using 
this approach for teaching professional development by collaborating in working according to the phase of Lesson Study in each week (every Monday for writing lesson plan by using Japanese mathematics textbook; Gakkoh Tosho Co., Ltd. in English version, and every Wednesday for reflecting the findings of knowledge management, or every Tuesday for writing lesson plan, and every Thursday for reflection in knowledge management together by spending duration after class in 3.305.00 p.m.

\section{Method}

This study collected data from fifty-eight primary school inservice teachers in "Project for Professional Development of Mathematics' teacher through Lesson Study and Open Approach" that focus on approaches to use mathematics textbooks while planning the lesson. The data were collected by Questionnaires: check lists, interviews and open ended questionnaires. To compare the approaches on teachers' use of mathematics textbook, before attend the project teachers use Thai mathematics textbook for planning the lesson and during attended the project teachers use Japanese mathematics textbook was the main resources to plan the lesson.

\section{Data Analysis}

The data were analysed based on framework on approaches to use textbooks'; adherence, elaboration and creation (Table 1) (Nicol \& Crespo, 2006) to classify the type in teachers' use of mathematics textbooks.

\section{Result}

Characteristics of teachers' use of mathematics textbook for teaching as shown in Figure 1.

Table 1.

The framework on approaches to use textbooks (Nicol \& Crespo, 2006).

\begin{tabular}{|c|c|}
\hline $\begin{array}{c}\text { Approaches to use } \\
\text { textbooks }\end{array}$ & Characteristics of use \\
\hline Adhering & $\begin{array}{l}\text { - Accepts text as the authority for what and how to } \\
\text { teach. } \\
\text { - Adheres to one main curriculum resource. } \\
\text { - Expects the text to provide routines/ structures for } \\
\text { students and teacher. } \\
\text { - Makes few or no adaptations to lesson, tasks, } \\
\text { problems, and exercises in text. If adaptations are made } \\
\text { they are superficial (contextual rather than conceptual). } \\
\text { - Does not see self as a resource. }\end{array}$ \\
\hline Elaborating & $\begin{array}{l}\text { - Considers text as a guide for what and how to teach. } \\
\text { - Considers the text as the main resource but elaborates } \\
\text { it with other resource. } \\
\text { - Elaborates and extends textbook lessons, tasks, } \\
\text { problems, and exercises. } \\
\text { - Makes conceptual and contextual elaborations. } \\
\text { - Sees self as a resource. }\end{array}$ \\
\hline Creating & $\begin{array}{l}\text { - Examines text with a "critical eye" for its potential } \\
\text { and limitations in deciding what and how to teach. } \\
\text { - Considers the text as one of many resources for teaching. } \\
\text { - Creates problems and questions using the text to } \\
\text { stimulate ideas for the structure, sequence, and context } \\
\text { of lessons. } \\
\text { - Adaptations are conceptual. } \\
\text { - Sees self as a knowledgeable resource for designing } \\
\text { problems. }\end{array}$ \\
\hline
\end{tabular}

In Figure 1, the mean of number on characteristics of using mathematics textbooks were as follows:

1) Accepts text as the authority for what and how to teach.

2) Considers text as a guide for what and how to teach.

3) Examines text with a "critical eye" for its potential and limitations in deciding what and how to teach.

4) Adheres to one main curriculum resource.

5) Considers the text as the main resource but elaborates it with other resource.

6) Considers the text as one of many resources for teaching.

7) Expects the text to provide routines/structures for students and teacher.

8) Elaborates and extends textbook lessons, tasks, problems, and exercises.

9) Creates problems and questions using the text to stimulate ideas for the structure, sequence, and context of lessons.

10) Makes few or no adaptations to lesson, tasks, problems, and exercises in text. If adaptations are made they are superfi cial (contextual rather than conceptual).

11) Makes conceptual and contextual elaborations.

12) Adaptations are conceptual.

13) Does not see self as a resource.

14) Sees self as a resource.

15) Sees self as a knowledgeable resource for designing Problems.

The results on the approaches on teachers' use of mathematics textbook found that the percentage of adherence and elaboration decrease and the percentage of creation increase after teachers attend the project as show in Figure 2.

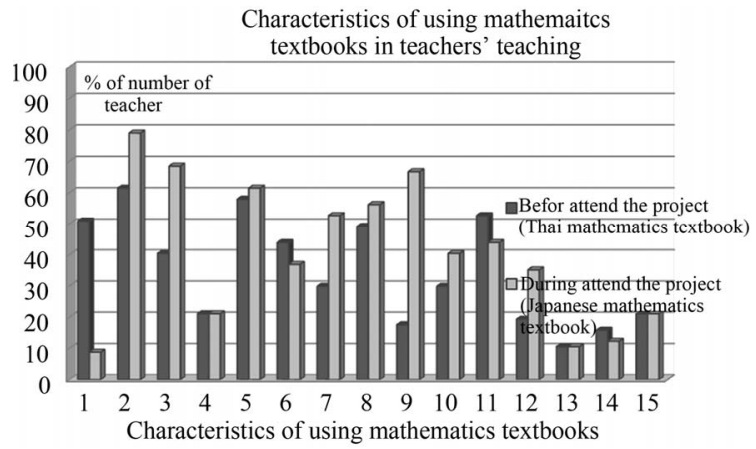

Figure 1.

Percentage on the characteristics of using mathematics textbooks in teachers' teaching.

Approach of mathematics' teacher textbook use

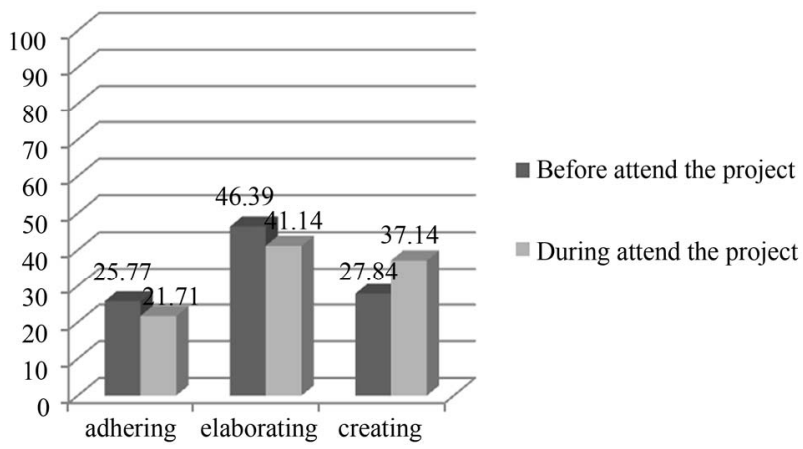

Figure 2.

Percentage of the approaches on teachers' use of mathematics textbook. 


\section{Conclusion and Discussion}

Leung (1992) state that teachers in different countries not only the mathematics textbooks but also the approaches on teachers' use of mathematics textbook were different. The structure of Thai mathematics textbooks consisted of exercise with skill practice in calculation, and exercise for reviewing rule and principle (Inprasitha, 1997) and structure of Japanese mathematics textbook was problem solving structure consisted of problem situations, various approaches and solutions from students' mathematical ideas and important mathematical concept (Takahashi, 2006). Then the result of this research indicated that the approach of Thai teachers use of Japanese mathematics textbook (during attend the project) were different from Thai teachers' use of Thai textbooks (before attend the project.) were the approach on teachers' use of mathematics textbook; adherence and elaboration decrease and creation increase after teachers attend the project.

Inprasitha (2010) state that lesson Study in Thai context, teachers used Japanese mathematics textbooks was the main resource for implementation of teacher and researcher group collaboration in planning the lesson for mathematics classroom, in order to determine the topic of teaching, design the openended problem situation, design and construct the material and equipment, use for determining the sequence of directions for activity and the teacher's questions to be in used in classroom, as well as using the anticipation in the students' answer or ideas that might occur in class in order to prepare readiness of supplementary material (the material using for supporting and showing the students' occurred answer/ideas), schedule the time in each topic to be taught in order to achieve shared goal of lesson. Lesson Study is the new context for Thai teachers to improve professional development. Then, Lesson Study were an important part to supported the approaches on Thai teachers' use of mathematics textbook during attend the project.

\section{Acknowledgements}

The authors would like to thank the Office of the Higher Education Commission, Thailand for supporting by grant fund under the program Strategic Scholarships for Frontier Research Network for the Ph.D. Program Thai Doctoral degree for this research, Center for research in Mathematics Education and Graduate School, Khon Kaen University, Thailand.

\section{REFERENCES}

Haggarty, L., \& Pepin, B. (2001). An investigation of mathe matics textbooks and their use in English, French and German Classrooms: Who gets an Opportunity to learn what? Proceedings of the British Society for Research into Learning Mathematics, 21, London: Carfax Publishing.

Inprasitha, M. (1997). Problem solving: A basis to reform mathematics instruction. The Journal of the National Research Council of Thailand, 29, 221-259.

Inprasitha, M., \& Loipha, S. (2007). Developing student's mathematical thinking through lesson study in Thailand. Progress Report of the APEC Project: Collaborative Studies on Innovations for Teaching and Learning Mathematics in Different Cultures (II)-Lesson Study Focusing on Mathematical Thinking, Center for Research on International Cooperation in Educational Development.

Inprasitha, M. et al. (2007). Preparing contexts for use Japanese's teacher professiona development "Lesson Study" in Thailand. Proceeding of the 1st Conference of the National Japan Education's Network in Thailand, 152-163.

Inprasitha, M. (2010). One feature of adaptive Lesson Study in Thailand: Designing learning unit. Proceedings of the 45th National Meeting of Math. Ed., Gyeongju, 8-10 October 2010.

Lewis, C. (2002). Lesson study: A handbook of teacher-Led instructtional change. Philadelphia, PA: Research for better Schools.

Lewis, C., Perry, R., \& Hurd, J. (2004). A deeper look at lesson study. Educational Leadership.

Fan, L., \& Zhuo, Y. (2002). Textbook use by singaporean math ematics teachers at lower secondary school level. URL (last checked 18 July 2002).

www.mste.uiuc.edu/courses/ci431sp02/students/kharmon/kharmonP APER1.doc

Fan, L., \& Zhuo, Y. (2007). Presentation of problem-solving procedures: A comparative look at China Singapore,and US mathematics textbooks. In T. Dreyfus (Eds.), Educational Studies in Mathematics (pp. 61-76). Berlin: Springer.

Loipha, S., \& Inprasitha, M. (2004). Professional development to promoting mathematics learning. KKU Journal of Mathematics Education, 1, 18-28.

Moulton, J. (1997). How do teacher use textbooks? A review of the literature. Africa Bureau Information Center (ABIC). No. 74.

Murata, A. (2007). Role of representations in the US and Japanese curricula: Learning in and outside of contexts. In T. Lamberg, \& L. R. Wiest (Eds.), Proceedings of the 29th Annual Meeting of the North American Chapter of the International Group for the Phychology of Mathematics Education, Stateline (Lake Tahoe). Reno: University of Nevada.

Takahashi, A. (2006). Characteristics of Japanese mathematics lessons. Tsukuba Journal of Educational Study in Mathematics. Hamamatsu: Maeda Printing Co., Ltd.

Watanabe, T., Takahashi, A., \& Yoshida, M. (2008). Kyozaikenkyu: A critical step for conducting effective lesson study and beyond. Inquiry into Mathematics Teacher Education, 131-142. 